\title{
TRANS-SYNAPTIC MODULATION OF HISTAMINE H-1 RECEPTOR DEVELOPMENT IN RAT BRAIN ${ }^{1}$
}

\author{
N. SUBRAMANIAN, W. L. WHITMORE, AND T. A. SLOTKIN ${ }^{2}$
}

Department of Pharmacology, Duke University Medical Center, Durham, North Carolina 27710

\begin{abstract}
To determine whether neuronal histamine influences development of histamine $\mathrm{H}-1$ receptors in the rat brain, neonates were given diphenhydramine, an $\mathrm{H}-1$ antagonist, daily for the first 21 days of postnatal life. In control rats, specific $\mathrm{H}-1$ binding of $\left[{ }^{3} \mathrm{H}\right]$ mepyramine in whole brain was low at birth and increased progressively toward adult levels by the end of the 3rd week. Animals treated with diphenhydramine showed marked elevations in binding as early as 4 days postnatally and the differences persisted throughout the experimental period. The increased binding in treated rats was specific to treatment with $\mathrm{H}-1$ antagonists (diphenhydramine, mepyramine) as opposed to an $\mathrm{H}-2$ antagonist (cimetidine); the alteration reflected enhancement of the number of binding sites without a change in $K_{d}$, a finding indicative of $\mathrm{H}-1$ receptor supersensitivity. Similar results were seen in the hypothalamus, an area rich in neuronal histaminergic projections. Levels of histamine in the hypothalamus were unaffected by diphenhydramine administration until the end of the 3rd week, at which time, increases were noted. After the loading of the hypothalamus with $\left[{ }^{3} \mathrm{H}\right]$ histamine, release of label by $\mathrm{K}^{+}$depolarization in vitro (an indirect index of release from the neuronal histamine pool) was readily obtained at all ages and was unaffected by diphenhydramine administration. Diphenhydramine did not alter histamine levels in brain regions in which most of the histamine is nonneuronal. These studies suggest that, even early in the ontogenesis of histaminergic synapses, a sufficient proportion of releasable histamine is associated with histaminergic neurons to enable trans-synaptic modulation of development of histaminergic $\mathrm{H}-1$ receptors; consequently, blockade of these receptors with diphenhydramine results in supersensitivity even at the earliest stages of development.
\end{abstract}

Evidence from biochemical, anatomical, and electrophysiological studies suggests that histamine is a neurotransmitter in the central nervous system (Green et al., 1978; Schwartz et al., 1979, 1980a). Responses to histamine in the brain are mediated by both $\mathrm{H}-1$ and $\mathrm{H}-2$ receptors; while cyclic nucleotide alterations are mediated predominantly by $\mathrm{H}-2$ receptors (Schwartz et al., 1980h), H-1 receptors are responsible for release of catecholamines (Subramanian and Mulder, 1977; Subramanian, 1979), glycogenolysis (Schwartz et al., 1980b), and increased turnover of phospholipids (Subramanian et al., 1980). In the case of histamine, the use of standard techniques for evaluating the ontogeny of neurotransmitter stores and receptor-mediated responses is complicated by the fact that large stores of non-neuronal histamine are present in some regions of the developing

\footnotetext{
${ }^{1}$ This work was supported by United States Public Health Service Grants HD-09713 and HL-24115.

${ }^{2}$ Recipient of Research Scientist Development Award DA-00006 from the National Institute of Drug Abuse. To whom correspondence should be addressed at Box 3813, Department of Pharmacology, Duke University Medical Center, Durham, NC 27710.
}

brain and because some of the histaminergic receptor binding sites may be located outside of the neuronal compartment (Schwartz et al., 1980b; Karnushina et al., 1980; Marco et al., 1980; Subramanian et al., 1981). However, in a recent study (Subramanian et al., 1981), some of these problems have been overcome by comparing the development of the transmitter in regions rich in neuronal histamine (hypothalamus) with regions in which most of the histamine is associated with mast cells (cerebellum, pons). Using $\left[{ }^{3} \mathrm{H}\right]$ mepyramine as a radioligand for $\mathrm{H}-1$ receptors, it was found that the development of this histaminergic receptor subtype did in fact parallel the development of neuronal histamine stores in a pattern similar to that reported for histidine decarboxylase (EC 4.1.1.22), a more specific marker for histaminergic nerve terminals (Subramanian et al., 1981; Schwartz et al., 1971; Tran et al., 1980); H-1 receptors in whole brain gave virtually the same pattern as that seen previously in hypothalamus. Additionally, the ability of intracisternally administered histamine to stimulate whole brain phospholipid turnover, an event linked to $\mathrm{H}-1$ receptors associated solely with neuronal histamine (Subramanian et al., 1980), correlated well with development of neuronal 
histamine projections (Subramanian et al., 1981). These observations raised the possibility that the maturation of histaminergic neurotransmission is a coordinated process where development of neuronal histamine (as reflected in hypothalamic histamine levels and histidine decarboxylase activity) influences the ontogeny of histamine $\mathrm{H}-1$ receptors and of the cellular events mediated by these receptors. To test this hypothesis, in this study, we have examined whether the number or sensitivity $\left(K_{d}\right)$ of receptors could be influenced early in development by repeated administration of an antihistamine. If transsynaptic regulation of receptor maturation occurs, then it would be expected that receptors would be affected even at the earliest stages of development of histaminergic synapses. In addition, the possible effects of antihistamines on development of presynaptic histaminergic function have been evaluated through measurement of histamine in brain regions and by measuring depolarization-induced release of $\left[{ }^{3} \mathrm{H}\right]$ histamine from hypothalamic slices, an index of releasability of neuronal histamine (Subramanian and Mulder, 1976; Schwartz et al., 1979).

\section{Materials and Methods}

Timed pregnant Sprague-Dawley rats (7ivic-Miller, Allison Park, PA) were housed individually in breeding cages in animal quarters and maintained on a 12-hr dark12-hr light cycle with water and standard diet available ad libitum. Pups from all litters were randomized at birth and redistributed to the nursing mothers, a procedure which was repeated on subsequent alternate days. Litter sizes were kept at 8 to 10 to ensure a uniform nutritive status. The pups received daily subcutaneous injections of diphenhydramine (Benadryl, Parke, Davis \& Co., Detroit, MI; injection volume, $1 \mu \mathrm{l} / \mathrm{gm}$ of body weight) at a dose of $10 \mathrm{mg} / \mathrm{kg}$, while control pups received an equal volume of saline. In some experiments, rats were treated daily with $10 \mathrm{mg} / \mathrm{kg}$, s.c., of mepyramine (Smith Kline \& French, Philadelphia, PA) or $12.5 \mathrm{mg} / \mathrm{kg}$, s.c., of cimetidine (Smith Kline \& French). Drug-treated and control pups were killed at various ages, in each case, $24 \mathrm{hr}$ after the last injection. To avoid diurnal variation in the measured histamine levels (Orr and Quay, 1975), the pups were always killed between 8 and 9 AM.

$H-1$ receptor binding. Specific $\left[{ }^{3} \mathrm{H}\right]$ mepyramine binding associated with histamine $\mathrm{H}-1$ receptors was assayed essentially as described by Chang et al. (1978). Membrane preparations were obtained by homogenization of the whole brain or hypothalamus in $5 \mathrm{vol}$ of $0.05 \mathrm{~m}$ sodium phosphate buffer ( $\mathrm{pH} 7.45)$ and sedimentation of the membranes at $50,000 \times g$ for $20 \mathrm{~min}$. The pellet was resuspended, washed, and resedimented twice with $5 \mathrm{vol}$ of buffer and finally resuspended in 5 vol of buffer. Subsequently, $0.05 \mathrm{ml}$ of the membrane preparation (containing 0.10 to $0.15 \mathrm{mg}$ of protein) was incubated with 1.2 nM $\left[{ }^{3} \mathrm{H}\right]$ mepyramine (Amersham Corp., Arlington Heights, IL; $29 \mathrm{Ci} / \mathrm{mmol}$ ) with or without $5 \mu \mathrm{M}$ triprolidine to displace specific binding in a final volume of $2 \mathrm{ml}$. Following incubation at $37^{\circ} \mathrm{C}$ for $30 \mathrm{~min}$, the samples were chilled on ice and filtered through glass fiber filters (Gelman type A/E), washed three times with 2 -ml portions of ice cold buffer, and counted in $10 \mathrm{ml}$ of scintillation cocktail. All samples were run in triplicate for each individual animal at each time point. At some ages, remaining aliquots of the membrane preparations were pooled and Scatchard analysis was performed at $\left[{ }^{3} \mathrm{H}\right]$ mepyramine concentrations of 0.2 to $1.8 \mathrm{nM}$ in order to determine which binding parameter was affected. Protein in each sample was estimated by the method of Lowry et al. (1951).

IIistamine levels. The brain was dissected quickly over chilled glass plates into hypothalamus, pons + cerebellum, and the rest of the brain, and each region was weighed and homogenized quickly in $2 \mathrm{ml}$ of $0.1 \mathrm{M}$ sodium phosphate buffer, $\mathrm{pH}$ 7.4. Denaturation of histaminecatabolizing enzymes and extraction of histamine were accomplished by placing the homogenates in a boiling water bath for $10 \mathrm{~min}$ followed by centrifugation at 50,000 $\times g$ for $20 \mathrm{~min}$. The supernatant containing the histamine was frozen and stored at $-20^{\circ} \mathrm{C}$ until assay. Histamine was analyzed by the enzymatic-isotopic method of Taylor and Snyder (1972) using rat kidney as a source of histamine methyltransferase (EC 2.1.1.8) (Shaff and Beaven, 1979) and $S$-adenosyl-L- $\left[\right.$ methyl $\left.-{ }^{3} \mathrm{H}\right]$ methionine (Amersham Corp., $79 \mathrm{Ci} / \mathrm{mmol}$ ) as the methyl donor.

Potassium-induced efflux of $\left[{ }^{3} H\right]$ histamine from hypothalamic slices. As an index for releasability of histamine from neurons, depolarization-induced release of $\left[{ }^{3} \mathrm{H}\right]$ histamine was studied as described previously (Subramanian and Mulder, 1976). At selected ages, pairs of control and drug-treated neonates were killed, and tissue cubes (approximately $0.5 \times 0.5 \times 0.5 \mathrm{~mm}$ ) prepared from hypothalamus were preincubated with $0.55 \mu \mathrm{M}\left[{ }^{3} \mathrm{H}\right]$ histamine (Amersham Corp., $9 \mathrm{Ci} / \mathrm{mmol}$ ) for $15 \mathrm{~min}$ at $37^{\circ} \mathrm{C}$ in Krebs-Ringer bicarbonate buffer (KRB; composition: $\mathrm{NaCl}, 118 \mathrm{~mm} ; \mathrm{KCl}, 4.85 \mathrm{~mm} ; \mathrm{CaCl}_{2}, 2.5 \mathrm{~mm} ; \mathrm{MgSO}_{4}, 1.15$ $\mathrm{mm} ; \mathrm{KH}_{2} \mathrm{PO}_{4}, 1.15 \mathrm{~mm}$; $\mathrm{NaHCO}_{3}, 25 \mathrm{~mm}$; glucose, 11.1 $\mathrm{mm} ; \mathrm{pH} 7.2$ to 7.4 ) gassed with $95 \% \mathrm{O}_{2}$ and $5 \% \mathrm{CO}_{2}$ for 10 min. Subsequently, the slices were rinsed twice, carefully avoiding damage to the tissue, and transferred to superfusion cells ( $0.3 \mathrm{ml}$ volume, three to four slices per cell) maintained at $37^{\circ} \mathrm{C}$ by water circulating through an outer jacket. Tissues were superfused with KRB buffer at 0.25 $\mathrm{ml} / \mathrm{mm}$ until stabilization of the ${ }^{3} \mathrm{H}$ overflow was achieved (about $30 \mathrm{~min}$ ). Five fractions, each of $2 \mathrm{~min}$ duration, then were collected to record the spontaneous efflux; next, the depolarization-induced release was elicited by substituting $56 \mathrm{mM} \mathrm{K}^{+}$for $\mathrm{Na}^{+}$in the KRB and five additional fractions were collected. Finally, normal KRB was superfused again to restore the spontaneous rate of efflux, and five fractions were collected. At the end of the superfusion, the residual radioactivity in the tissue cubes was extracted with $3 \mathrm{ml}$ of $10 \%$ perchloric acid. All of the fractions as well as an aliquot of the tissue extract were counted for radioactivity, and results were expressed as the percentage released of the total radioactivity present in the slices (Subramanian and Mulder, 1976). Under these experimental conditions, it has been shown that neuronal histamine accounts for at least $80 \%$ of the depolarization-induced ${ }^{3} \mathrm{H}$ efflux (Subramanian and Mulder, 1976).

Statistics. Data are presented as means and standard errors with significance evaluated by the Student's $t$ test (two tailed, unpaired). Straight lines in the Scatchard analysis were fitted by least squares. A paired $t$ test was 
used to evaluate the effects of diphenhydramine on specific binding of $\left[{ }^{3} \mathrm{H}\right]$ mepyramine versus age; group means of control and experimental animals were paired by age over the entire course of development, enabling an overall comparison to be made, as opposed to comparisons only of individual age points in the unpaired $t$ test. In this case, degrees of freedom were calculated as the number of paired means minus 1 . Two-way analysis of variance also was performed to confirm the paired $t$ test (which is less sensitive) wherever the latter was utilized.

\section{Results}

$\left[{ }^{3} \mathrm{H}\right]$ Mepyramine binding to $\mathrm{H}-1$ receptors in whole brain preparations was low at 2 days of age in control rats and increased progressively toward mature values by the end of the 2nd week (Fig. 1). Pups treated with diphenhydramine exhibited a significant increase in binding as early as 4 days of age and values remained elevated throughout development ( $p<0.01$ by paired $t$ test). Scatchard analysis of the binding characteristics at 10 days of age revealed that the $K_{d}$ remained the same in both groups but that the number of binding sites was higher in the drug-treated pups (Fig. 2). A similar elevation was obtained in the hypothalamus and, again, was related to an increase in the number of sites (Table I).

To examine the specificity of the effect of diphenhydramine on $\mathrm{H}-1$ receptors in developing rats, studies were conducted with another $\mathrm{H}-1$ antagonist (mepyramine) and with an $\mathrm{H}-2$ antagonist (cimetidine). Mepyramine produced elevation of $\mathrm{H}-1$ specific binding identical to that caused by diphenhydramine, but cimetidine was totally ineffective (Table II).

Since antihistamines can inhibit specific binding of $\left[{ }^{3} \mathrm{H}\right]$ mepyramine when added to the assay system in vitro (Hill and Young, 1980; Chang et al., 1978; Schwartz et al., 1980b) or when injected into animals shortly before preparing the membrane fraction (Diffley et al., 1980), it was important to see if the $24-\mathrm{hr}$ pretreatment with 10 $\mathrm{mg} / \mathrm{kg}$ of diphenhydramine used in the current study had any effect on the assay. Two approaches were un-

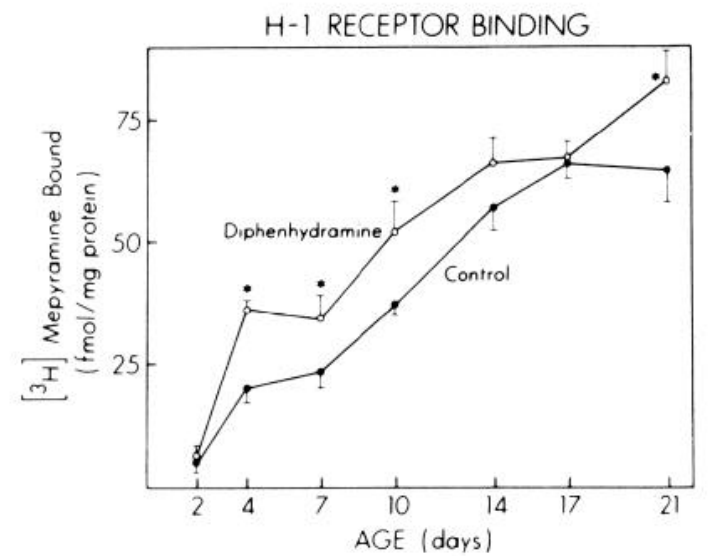

Figure 1. Specific binding of $\left[{ }^{3} \mathrm{H}\right]$ mepyramine to $\mathrm{H}-1$ receptors in developing whole brain of control and diphenhydraminetreated rats. Data represent mean $\pm \mathrm{SE}$ of six animals at each age. Asterisks denote significant elevations compared to controls ( $p<0.05$ or better by unpaired $t$ test). Overall developmental patterns are significantly different $(p<0.01$ by paired $t$ test).

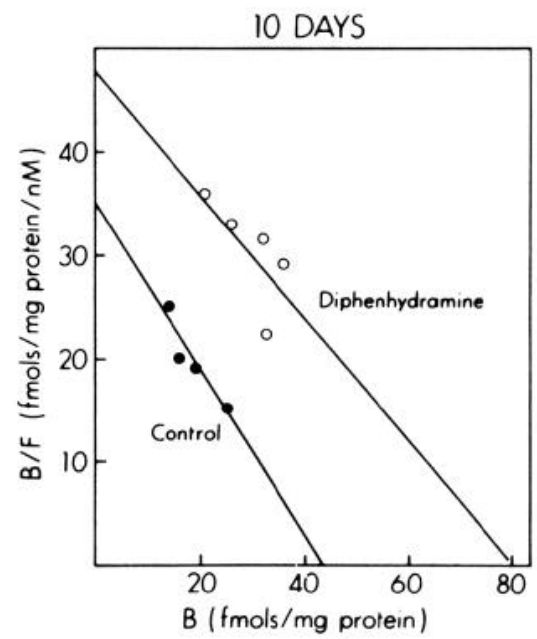

Figure 2. Scatchard analysis of $\left[{ }^{3} \mathrm{H}\right]$ mepyramine binding in rat brain preparations at 10 days of age. For controls, $K_{d}=1.2$ $\pm 0.2 \mathrm{nM}$ and number of sites $=43 \pm 1 \mathrm{fmol} / \mathrm{mg}$ of protein. For diphenhydramine-treated pups, $K_{d}=1.6 \pm 0.4 \mathrm{~nm}$ (not significant versus control) and number of sites $=80 \pm 3 \mathrm{fmol} / \mathrm{mg}$ of protein ( $p<0.001$ versus control). $B / F$, bound/free.

TABLE I

$\left[{ }^{3} \mathrm{H}\right]$ Mepyramine binding in hypothalamus of 10-day-old rats treated with daily injections of diphenhydramine $(10 \mathrm{mg} / \mathrm{kg})$

Data represent mean $\pm \mathrm{SE}$ of six animals. Specific binding was determined at $1.2 \mathrm{~nm}\left[{ }^{3} \mathrm{H}\right]$ mepyramine.

\begin{tabular}{|c|c|c|c|}
\hline Treatment & Specific Binding & $K_{d}$ & Maximum Binding \\
\hline & fmol/mg protein & $n M$ & fmol/mg protein \\
\hline Control & $38 \pm 4$ & 1.5 & 65 \\
\hline Diphenhydramine & $55 \pm 6^{a}$ & 1.5 & 104 \\
\hline
\end{tabular}

${ }^{a} p<0.01$ versus control.

TABLE II

Effects of daily administration of $\mathrm{H} \cdot 1$ and $\mathrm{H} \cdot 2$ antagonists on $\left[{ }^{3} \mathrm{H}\right]$ mepyramine binding to whole brain preparations from 6-day. old rats

Data represent mean $\pm \mathrm{SE}$ of six animals.

\begin{tabular}{lc}
\multicolumn{1}{c}{ Treatment } & Specific Binding \\
\hline & fmol/mg protein \\
Control & $27 \pm 3$ \\
Diphenhydramine (H-1) & $40 \pm 2^{a}$ \\
Mepyramine (H-1) & $39 \pm 4^{b}$ \\
Cimetidine (H-2) & $27 \pm 3$
\end{tabular}

${ }^{a} p<0.005$ versus control.

${ }^{b} p<0.05$ versus control.

dertaken: $(a)$ Rats were injected with diphenhydramine, and $\left[{ }^{3} \mathrm{H}\right]$ mepyramine binding was measured $24 \mathrm{hr}$ later and compared to that seen in untreated animals and $(b)$ brains from normal animals were homogenized in the presence of $0.1 \mathrm{mg}$ of diphenhydramine/gm of brain (more than 10 times the theoretical maximal brain level in vivo) and washed and processed in the manner described above. In neither case was the binding assay affected (data not shown).

Histamine levels in the pons + cerebellum and the rest of the brain (whole brain less hypothalamus, cerebellum, and pons) followed the pattern characteristic of nonneuronal histamine, i.e., high levels at birth declining over the first 2 weeks to the low concentrations typical of the adult (Fig. 3). An identical pattern was obtained in 


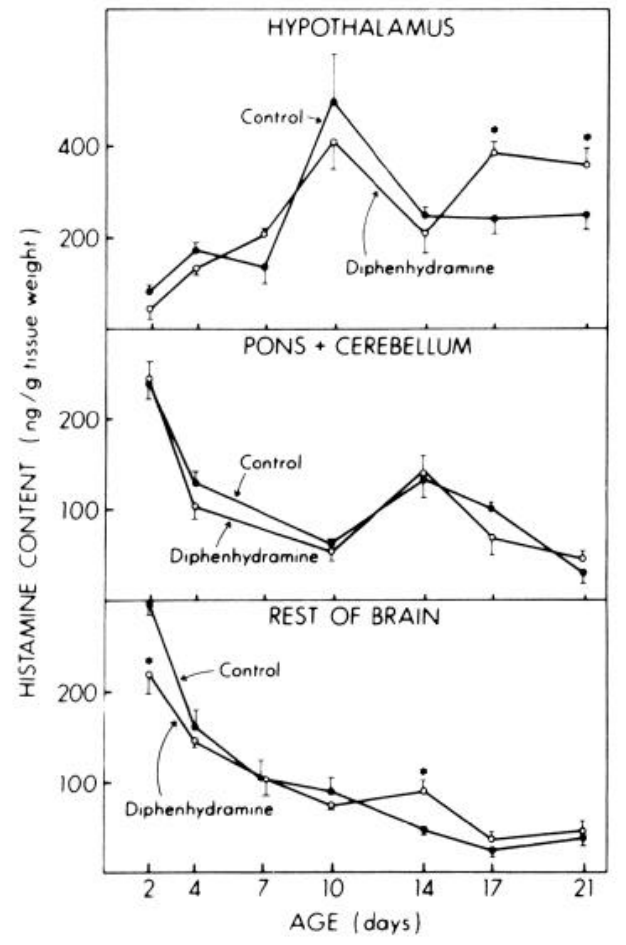

Figure 3. Histamine content in brain regions of developing control and diphenhydramine-treated rats. Data represent mean $\pm \mathrm{SE}$ of four animals at each age. Rest of brain denotes whole brain less hypothalamus, pons, and cerebellum. Asterisks indicate significant differences between control and diphenhydramine groups ( $p<0.05$ or better by unpaired $t$ test).

the diphenyhydramine-treated pups. In the hypothalamus, histamine content was lowest at birth and reached or exceeded adult values by 10 days, a pattern associated with neuronal histamine stores (Subramanian et al., 1981). Again, the diphenhydramine-treated animals exhibited a similar pattern, but a somewhat higher level of histamine was seen toward the end of the 3 rd week postnatally.

$\mathrm{K}^{+}$-induced release of $\left[{ }^{3} \mathrm{H}\right]$ histamine could be obtained readily at all ages in both control and diphenhydraminetreated groups. Examples of individual release experiments are shown in Figure 4.

Body weights, brain weights, and brain region weights were normal in the diphenhydramine-treated animals (data not shown).

\section{Discussion}

The ontogeny of $\mathrm{H}-1$ receptor binding sites was altered by postnatal administration of diphenhydramine. While there was no change in the $K_{d}$, the number of binding sites was higher than in the controls, thus producing a net increase in specific binding. This is typical of receptor supersensitivity resulting from blockade of neurotransmission (Gnegy and Costa, 1980). The effect was specific to H-1 antagonists. Since blockade of the actions of endogenous histamine by diphenhydramine produced changes in receptors even at 4 days, this study strongly suggests that the normal ontogenetic pattern of $\mathrm{H}-1$ receptor sites in the brain is modulated by exposure of the sites to histamine even at ages where only a small proportion of histaminergic synapses have formed. The

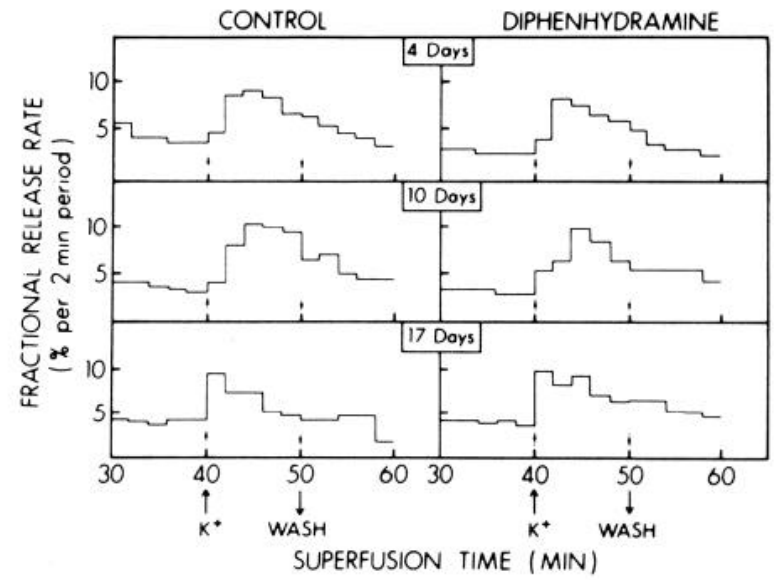

Figure 4. Representative examples of stimulation by $\mathrm{K}^{+}$of $\left[{ }^{3} \mathrm{H}\right]$ histamine efflux from pairs of hypothalami in developing control and diphenhydramine-treated rats. Upward arrow indicates the partial replacement of $\mathrm{Na}^{+}$with $56 \mathrm{mM} \mathrm{K} \mathrm{K}^{+}$and downward arrow indicates the subsequent washout period with normal $\mathrm{Na}^{+}$and $\mathrm{K}^{+}$. Similar results were obtained at all ages.

same elevations of $\mathrm{H}-1$ binding could be seen in hypothalamus, the main constituent of the ascending histaminergic pathway (Schwartz et al., 1980a), and it is likely, then, that neuronal histamine is involved in this modulation since, even in whole brain, the $\mathrm{H}-1$ receptors are linked to effects of histamine in the neuronal pool (Subramanian et al., 1980, 1981).

In order for neuronal histamine to influence $\mathrm{H}-1$ receptors during development, releasable histamine must be present in the nerve terminals. Since non-neuronal histamine is usually high in developing tissue (Schwartz et al., 1980b), it was important to demonstrate that histamine, in fact, was localized neuronally in regions with histaminergic projections (hypothalamus). The developmental pattern of histamine in the hypothalamus is typical of neurotransmitters and not of mast cells (Subramanian et al., 1981) and supports the view that at least some of the histamine has a neuronal locus. If this pool of histamine is regulating $\mathrm{H}-1$ receptor development, then a portion of the histamine should be releasable by $\mathrm{K}^{+}$-induced depolarization, which is known to release histamine primarily from the neuronal pool (Taylor and Snyder, 1973; Verdiere et al., 1975; Subramanian and Mulder, 1976). However, because of the low levels of histamine present at early ages in the hypothalamus, assessment of release of endogenous histamine (Taylor and Snyder, 1973) is not feasible. Consequently, an indirect, qualitative measurement of release was obtained by preloading the tissue with $\left[{ }^{3} \mathrm{H}\right]$ histamine; there are strong indications that at least some of the $\left[{ }^{3} \mathrm{H}\right]$ histamine labels the endogenous neuronal histamine pool (Subramanian and Mulder, 1976), although a conclusive demonstration of the specific locus of labeling cannot be performed in the neonate. Release of $\left[{ }^{3} \mathrm{H}\right]$ histamine was obtained readily at all ages. These data support the view that the neonate does possess neuronal histamine, that at least some of the histamine is available for release, and thus, that trans-synaptic control of the number of $\mathrm{H}-1$ receptors is feasible.

In addition to increasing the number of $\mathrm{H}-1$ receptors, 
diphenhydramine also produced an eventual elevation of hypothalamic histamine levels, confirming an earlier report in adults (Huszti, 1980); in contrast to receptor binding, the effect on histamine did not appear until the 3rd week postnatally. It has been postulated (Huszti, 1980) that the increase in histamine caused by $\mathrm{H}-1$ antagonists is brought about by a negative feedback control mechanism; if this is true, then control of histamine synthesis does not appear to develop until well after ontogeny of the $\mathrm{H}-1$ receptor system and trans-synaptic influence on the number of receptors. It is also possible that the large maturational increases in histamine synthesis associated with levels of histidine decarboxylase (Schwartz et al., 1971; Tran et al., 1980) mask any additional contribution of antihistamine treatment (Huszti, 1980). In either case, the effects of neonatal diphenhydramine treatment on brain histamine synthesis and/or levels appear to be restricted to the neuronal histamine pool since no effects were seen in brain areas in which most of the histamine is non-neuronal. Again, $\mathrm{K}^{+}$-induced release of $\left[{ }^{3} \mathrm{H}\right]$ histamine in the hypothalamus was obtainable in the diphenhydramine-treated animals.

In conclusion, the development of histaminergic $\mathrm{H}-\mathrm{I}$ receptors in the rat brain appears to be modulated by trans-synaptic input. Blockade of $\mathrm{H}-1$ receptors caused by diphenhydramine administration increases the number of $\mathrm{H}-1$ receptors even when only a small proportion of histaminergic synapses have formed.

\section{References}

Chang, R. S. L., V. T. Tran, and S. H. Snyder (1978) Histamine $\mathrm{H}-1$ receptors in brain labeled with ${ }^{3} \mathrm{H}$-mepyramine. Eur. J. Pharmacol. 48: 463-464.

Diffley, D., V. T. Tran, and S. H. Snyder (1980) Histamine H1 receptors labeled in vivo: Antidepressant and antihistamine interactions. Eur. J. Pharmacol. 64: 177-181.

Gnegy, M. E., and E. Costa (1980) Catecholamine receptor supersensitivity and subsensitivity in the central nervous system. In Essays in Neurochemistry and Neuropharmacology, M. B. H. Youdim, W. Lovenberg, D. F. Sharman, and J. R. Lagnado, eds., pp. 249-282, John Wiley and Sons, New York.

Green, J. P., C. L. Johnson, and H. Weinstein (1978) Histamine as a neurotransmitter. In Psychopharmacology: A Generation of Progress, M. A. Lipton, A. DiMascio, and K. F. Killam, eds., pp. 319-332, Raven Press, New York.

Hill, S. J., and J. M. Young (1980) Histamine H-1 receptors in the brain of guinea-pig and the rat: Differences in ligand binding properties and regional distribution. Br. J. Pharmacol. 68: 687-696.

Huszti, Z. (1980) Regulation of histamine synthesis: Altered synthesis and level of histamine in the hypothalamus of rats by repeated administration of histamine $\mathrm{H}-1$ and $\mathrm{H}-2$ antagonists. Agents Actions 10: 98-100.

Karnushina, I. L., J. M. Palacios, G. Barbin, E. Dux, F. Joo, and J. C. Schwartz (1980) Studies on a capillary-rich fraction isolated from rat brain: Histaminic components and charac- terization of the histamine receptors linked to adenylate cyclase. J. Neurochem. 34: 1201-1208.

Lowry, O. H., N. J. Rosebrough, A. L. Farr, and R. J. Randall (1951) Protein measurements with Folin phenol reagent. J. Biol. Chem. 193: 265-275.

Marco, E. J., G. Balfagon, J. Main, B. Gomez, and S. Lluch (1980) Indirect adrenergic effect of histamine in cat cerebral arteries. Naunyn-Schmiedebergs Arch. Pharmacol. 312: 239243.

Orr, E. L., and W. B. Quay (1975) The effect of castration on histamine levels and 24 hour rhythm in the male rat hypothalamus. Endocrinology 97: 481-484.

Schwartz, J. C., C. Lampart, C. Rose, M. C. Rehault, S. Bischoff, and $H$. Pollard (1971) Histamine formation in rat brain during development. J. Neurochem. 18: 1787-1789.

Schwartz, J. C., G. Barbin, M. Baudry, M. Garbarg, M. P. Martres, H. Pollard, and M. Verdiere (1979) Metabolism and functions of histamine in the brain. Curr. Dev. Psychopharmacol. 5: 173-261.

Schwartz, J. C., H. Pollard, and T. T. Quach (1980a) Histamine as a neurotransmitter in the mammalian brain: Neurochemical evidence. J. Neurochem. 35: 26-33.

Schwartz, J. C., G. Barbin, A. M. Duchemin, M. Garbarg, J. M. Palacios, T. T. Quach, and C. Rose $(1980 \mathrm{~h})$ Histamine receptors in the brain: Characteristics by binding studies and biochemical effects. In Receptors for Neurotransmitters and Peptide Hormones, G. Pepeu, M. J. Kuhar, and S. J. Enna, eds., pp. 169-182, Raven Press, New York.

Shaff, R. E., and M. A. Beaven (1979) Increased sensitivity of the enzymatic-isotopic assay of histamine: Measurement of histamine in plasma and serum. Anal. Biochem. 94: 425-430.

Subramanian, N. (1979) Depletion of noradrenaline in the rat brain by histamine. Indian J. Pharmacol. 11: 173-180.

Subramanian, N., and A. H. Mulder (1976) Potassium-induced release of tritiated histamine from rat brain slices. Eur. J. Pharmacol. 35: 203-206.

Subramanian, N., and A. H. Mulder (1977) Modulation by histamine of the efflux of radiolabeled catecholamines from rat brain slices. Eur. J. Pharmacol. 43: 143-152.

Subramanian, N., F. J. Seidler, W. L. Whitmore, and T. A. Slotkin (1980) Histamine stimulates brain phospholipid turnover through a direct, $\mathrm{H}-1$ receptor mediated mechanism. Life Sci. 27: 1315-1319.

Subramanian, N., W. L. Whitmore, F. J. Seidler, and T. A. Slotkin (1981) Ontogeny of histaminergic neurotransmission in the rat brain: Concomitant development of neuronal histamine, $\mathrm{H}-1$ receptors and $\mathrm{H}-1$ receptor mediated stimulation of phospholipid turnover. J. Neurochem. 36: 1137-1141.

Taylor, K. M., and S. H. Snyder (1972) Isotopic microassay of histamine, histidine decarboxylase and histamine methyltransferase in brain tissue. J. Neurochem. 19: 1343-1358.

Taylor, K. M., and S. H. Snyder (1973) The release of histamine from tissue slices of : at hypothalamus. J. Neurochem. 21: 1215-1223.

Tran, V. T., A. D. Freeman, R. S. L. Chang, and S. H. Snyder (1980) Ontogenetic development of histamine H-1 receptor binding in the rat brain. J. Neurochem. 24: 1609-1613.

Verdiere, M., C. Rose, and J. C. Schwartz (1975) Synthesis and release of histamine on slices from rat hypothalamus. Eur. J. Pharmacol. 34: 157-168. 